\title{
Household Savings and Women's Bargaining Power in Ghana
}

\section{Afoakwah C ${ }^{1 *}$, Annim SK² and Peprah JA ${ }^{2}$}

${ }^{1}$ University of Ghana, Ghana

${ }^{2}$ University of Cape Coast, Cape Coast, Ghana

\begin{abstract}
This study investigates the effect of women's bargaining power on household's ownership and amount of savings in Ghana. Unlike previous empirical studies, this study considers the differences in preference among household members that leads to bargaining over allocation of resources in the household. To achieve the objective of this paper, the fifth round (2005) of the Ghana Living Standards Survey was employed. Women's bargaining power is measured as the share of woman's education among the couple. Probit and Heckman two-stage estimation techniques are employed. The latter is justified, in view of potential sampling selection bias in the annual savings model. The main finding is that, an increase women's bargaining power engenders a corresponding increase in the probability of ownership of savings account and amount saved. We therefore recommend that, one of the strategies to improve household savings habit in Ghana, is through empowering women via better education.
\end{abstract}

Keywords: Household savings; Women's bargaining power; Probit; Heckman two-stage; JEl Codes C25, C29

\section{Introduction and Motivation}

Financial services play an important role in the development of national economies. Sutton and Jenkins [1] as well as Honohan [2] argued that countries that have well established, efficient and properly utilized financial systems have less poverty. Several studies have concluded that strengthening the financial sector leads to poverty reduction [3-5]. Increasing rate of savings and investment does not only contribute to increasing rates of economic growth but also positive government savings, and strong increase in private savings engender positive per capita real growth. While savings is a crucial determinant of welfare in many developing countries where insurance and credit markets are lacking, Gravelle and Rees [6] argue that this is demonstrated in its ability to smoothen out the unexpected income variations and other shocks faced by economic agents.

Given the important role of savings at the household level and national level it is therefore necessary for individuals and policy makers to be interested in issues that will lead to increases savings among households. In Ghana, Basu et al. [7] argue that only 5 to 6 percent of the population is reported to have access to the commercial banking sector while 16 percent have access to an account with a financial intermediary World Bank [8]. In 2010, the percentage of Ghanaian that owned savings account was 23.80 and $38.50 \%$ in 2011 . Savings in Ghana over the past two decades has on average reduced which has had significant impact on investment [9]. There is therefore the need to investigate the factors that contributes to increase in savings

In a study by Ferber [10], he identified three related areas of financial management that couple bargain. The first is money management-"an arrangement within the family for the handling of money, payment of bills, budgeting, and keeping accounts". A second area identified by Ferber [10] is saving behaviour "the allocation of available financial resources for a given period between spending and saving, specifically what amount or proportion of these total resources should be allocated to saving and what proportion or amount to spending." The third and final area of financial management is asset management. Information about marital roles in both areas is very scarce and generally limited to one question about who takes care of savings or life insurance. This bargaining over resource allocation leads to positive outcomes. A study by Imai, Annim, Kulkarni, and Gaiha reveals that women's bargaining power improves the health of children in the household. Another study by Frempong showed that increase in women's bargaining power increases households food diversity index, a sign of increased household nutritional status. Despite the important role that women bargaining power play in the allocation of resources in the household, there have been limited studies investigating how women bargaining power impacts on the households' savings in Ghana. This study therefore attempts to test two main hypotheses: (1) women's bargaining power significantly affects household savings account ownership in Ghana, (2) women's bargaining power significantly affects household annual savings in Ghana.

\section{Literature}

\section{Measurement of women's bargaining power}

Bargaining power by definition is the relative ability for one party to exert influence over the other in negotiation. Although clear in definition, bargaining power is a difficult concept to measure. Economic researchers rely on proxy to capture bargaining power between couples in the household. Popular among these proxies are education, income and spousal age difference. The use of either of these proxies depends on the focus of what one is investigating. Problems may arise in interpreting bargaining power if one does not clearly spell out what he/she is estimating. For example in defining bargaining power in a savings model, Lundberg and Ward-Batts [11] include three variables as measures of the wife's relative bargaining power: (1) the difference in age between the husband and wife, (2) the difference in education between the husband and wife, and (3) the wife's share of current income. However, questions are raised about the interpretation

*Corresponding author: Clifford Afoakwah, University of Ghana, Ghana, Tel: +233209026102; E-mail: afoakwahclifford@yahoo.com

Received March 30, 2015; Accepted May 08, 2015; Published May 18, 2015

Citation: Afoakwah C, Annim SK, Peprah JA (2015) Household Savings and Women's Bargaining Power in Ghana. J Glob Econ 3: 139. doi:10.4172/2375-4389.1000139

Copyright: (c 2015 Afoakwah C, et al. This is an open-access article distributed under the terms of the Creative Commons Attribution License, which permits unrestricted use, distribution, and reproduction in any medium, provided the original author and source are credited. 
of the income share variable as a measure of bargaining power because relative earnings will reflect relative wage rates, which affect time use and savings through the prices of the husband's and the wife's time. Thus, this measure is likely to be endogenous with respect to savings behaviour. The problem with age as a measure of bargaining power in a savings model is that it raises doubts as to whether elderly wives necessarily have more power if their re-marriage probabilities decline with age. Given these doubts, the preferred measure of bargaining power in a savings model is based on differences in education as employed by Gibson et al. [12]. According to Doss, [13] education makes a woman a credible threat in the marriage because her probability of surviving outside the marriage is very high. This study therefore proxy women's bargaining power with education.

\section{Empirical studies on women's bargaining power and household savings}

On the relationship between bargaining power and savings in the household, Lundberg and Ward-Batts [11] analysed the Health and Retirement Study (HRS), a national longitudinal survey of older Americans, which began in 1992 and found that in America simple measures of relative bargaining power do not have significant effects on household assets, however, the difference between husband's education and wife's education significantly lowers net worth conditional on other household characteristics. Thus, households in which the husband has at least eight years more education than his wife have, they accumulate lower net wealth. This explains that greater men bargaining power over women in the household has a negative effect on households' net worth.

Another study that looks at the relationship between bargaining power and savings in the household is the study by Gibson et al. [12], who applied Ordinary Least Square regression on a cross sectional data from New Zealand and found that when women have greater relative bargaining power, households will accumulate lower levels of wealth. Their reason for such pattern was that since wives are typically younger than their husbands and have longer life expectancy, they have to finance a longer expected retirement period. Thus, they argued that higher women's bargaining power lowers household net wealth among pre-retirement couples.

\section{Methods}

\section{Data and methodology}

Data for the study was solely secondary data. Specifically, this study uses the fifth round of the Ghana Living Standard Survey (GLSS 5). The GLSS 5 was collected by the Ghana Statistical Service (GSS) between 2005 and 2006. The GLSS collects data on the socio-economic circumstances of the sample which helps to track the wellbeing of Ghanaians and also serve as source of information for national accounts. The unit of analysis used for the study is monogamous Ghanaian households.

In line with the stated hypotheses, this study follows the pooled income models specifically the cooperative bargaining mode. In this model, we assume that the household is made up of three parties, thus the husband (h), wife (w) and other members in the house (m). These other members are classified as non-income earners for the purpose of this study. We also assume that these household participants have varied preferences and household income is pooled. Suppose that each member of the household derives utility from two composite goods: savings (S), and non-savings goods $(\mathrm{N})$. Where $\mathrm{S}$ is savings, and it is a function of its price index $(\mathrm{P})$, and taste factors of the individuals proxied with that of the household head is $\mathrm{l}^{\mathrm{i}}$, while household level characteristics are captured by $l^{z}$.

The welfare weight of the husband and wife are assumed to be $\Phi^{h}$ and $\Phi^{w}$ respectively. This sum up to one signifying that the welfare weight of the other household member $\Phi^{m}=0$ implying that they have no bargaining power in the house. Furthermore we assume that the household income $\mathrm{y}^{\mathrm{z}}$ is an aggregate of that of the husband $\left(\mathrm{y}^{\mathrm{h}}\right)$ and wife $\left(y^{w}\right)$ all other household income $\mathrm{y}^{\mathrm{m}}$ are considered unearned income.

With a given household income, it is assumed that savings in the household is determined by the bargaining power of both parties. The bargaining power of the woman is given as the ratio of her years of schooling to the summation of her years of schooling and that of the husband. The bargaining power of the wife $\phi^{\mathrm{w}}$ is expressed as the function of the distributional factors. Where $E^{w}$ captures years of schooling of the woman and $\mathrm{E}^{\mathrm{h}}$ is the years of schooling of the husband

The maximization problem of the household is stated as:

$\max _{S, N} U^{z}=\Phi^{h} U^{h}(S, N)+\Phi^{w} U^{w}(S, N)$

Subject to

$y^{z}=S P_{s}+N P_{n}$

where

$y^{z}=y^{h}+y^{w}+y^{m}$
$\hat{O}^{w}=\hat{O}^{w}\left(\frac{E^{w}}{E^{w}+E^{m}}\right) \hat{O}^{i} \neq k$

And

$\hat{O}^{h}=\hat{O}^{h}\left(1-\hat{O}^{w}\right)$

The first-order conditions of the optimization problem are

$$
\begin{aligned}
& L=(S, N, ?)=\Phi^{h} U^{h}(S, N)+\Phi^{w} U^{w}(S, N)+\lambda\left(y^{z}-S P_{s}-N P_{n}\right) \\
& \frac{\partial L(.)}{\partial S}=\Phi^{h} \frac{\partial U^{h}(.)}{\partial S}+\Phi^{w} \frac{\partial U^{h}(.)}{\partial S}-\lambda P_{s}=0 \\
& \frac{\partial L(.)}{\partial N}=\Phi^{m} \frac{\partial U^{m}(.)}{\partial N}+\Phi^{m} \frac{\partial U^{w}(.)}{\partial N}-\lambda P_{N}=0 \\
& \frac{\partial L(.)}{\partial \lambda}=y^{z}-S P_{s}-N P_{n}=0
\end{aligned}
$$

Solving the household's constrained optimization problem, gives an optimal savings function S, as a function of prices, household income, bargaining power, individuals and household level characteristics that are discussed in the section on definition and measurement of variables. The demand function for Savings is therefore

$$
S=s\left(P_{s}, P_{n}, y^{z}, \Phi^{w}, l^{i}, l^{z}\right)
$$

The probit model to estimate ownership of savings account is specified as

$$
\begin{aligned}
& \operatorname{Pr}\left(S_{\text {acc } i=1 \mid x_{i}}\right)=\beta_{0}+\beta_{1} \text { Age }_{i}+\beta_{2} \text { loginc }_{i}+\beta_{3} B_{\text {power }_{i}}+\beta_{4} B_{\text {powersq }_{i}}+\beta_{5} \text { Dep }_{i}+ \\
& \beta_{6} \text { Hhsize }_{i}+\beta_{7} \text { Male }_{i}+\beta_{8} \text { Rel }_{i}+\beta_{9} \text { Reg }_{i}+\beta_{10} \text { Urban }_{i}+\varepsilon_{i}
\end{aligned}
$$

Employing Heckman model due to sample selection bias, we specify our outcome equation as follows

$$
\begin{aligned}
& \mathrm{S}_{\text {amt }}=+\beta_{1} \text { Age }_{i}+\beta_{2} \text { loginc }_{i}+\beta_{3} B_{-} \text {power }_{i}+\beta_{4} B_{-} \text {powersq }_{i}+\beta_{5} \text { Dep }_{i}+\beta_{6} \text { Hhsize }_{i}+ \\
& \beta_{7} \text { Male }_{i}+\beta_{8} \text { Rel }_{i}+\beta_{9} \text { Reg }_{i}+\beta_{10} \text { Urban }_{i}+\varepsilon_{i}
\end{aligned}
$$

while the participation/selection equations as

$\operatorname{Pr}\left(S_{\text {acc }} i=1 \mid x_{i}\right)=\beta_{0}+\beta_{1}$ Age $_{i}+\beta_{2}$ loginc $_{i}+\beta_{3} B_{\text {power }}+\beta_{4} B_{\text {powersq }}+\beta_{5}$ Dep $_{i}+\beta_{6}$ Hhsize $_{i}+\beta_{7}$ Male $_{i}+\beta_{8}$ Rel $_{i}$ $+\beta_{9}$ Reg $_{i}+\beta_{10}$ Urban $_{i}+\beta_{11}$ Borrow $_{i}+\beta_{12}$ Formal $_{i}+\varepsilon_{i}$ 
Where Formal and Borrow are the exclusive restrictions. Formal is a dummy for whether the household head is engaged in formal sector activity. In Ghana, formal sector workers require savings account into which their salary will be paid, however, their annual savings may not be directly influence by whether they are in the formal sector or not. Borrow is also binary and captures whether the household has borrowed within the study period or not. In Ghana, most financial institutions require borrowers to save savings accounts in order to deposit the borrowed funds into the account. However, this may not directly influence the quantum of their annual savings. The pair wise correlation test conducted supports this intuition, making them quality as exclusive restriction in the Heckman model. Table 1 provides information on variable definition and measurement as well as a priori expectations (Appendix 1).

\section{Results and Discussion}

\section{Descriptive statistics}

Figure 1 shows that at five percent significance level, account ownership among males is dominates the account ownership among females. While the proportion of males owning savings account is 30 percent the corresponding percentage for females is 24 . This is validated by the report of the Ghana Statistical services (Figure 1).

Also at one percent significance level, there are differences in bargaining power among women across the ten administrative regions in Ghana. The regional dimensions of women's bargaining power shows that among the seven regions in the southern part of Ghana, women in the Greater Accra region on the average have more bargaining power compared to their fellow in other six regions. The Central region although comes after the Greater Accra region, it precedes the Ashanti region, Eastern region, Western region, Volta region, and the Brong Ahafo region. In the northern part of Ghana, the study showed that the women in the Upper East region have a relatively high bargaining power followed by the northern region and the Upper West region. On the whole it can be realized that bargaining power among women in the northern part of Ghana is very low compare to that of women in the southern part of Ghana as shown in Figure 2.

Women in urban settings have more bargaining power than women in rural settings. On the average the study found that the bargaining power of a woman in an urban area in Ghana is twice the

\begin{tabular}{|c|c|c|}
\hline Variable & Definition & A priori sign \\
\hline Sacc & Owning saving account & \\
\hline Age & Age of household head & positive \\
\hline loginc & Household income & positive \\
\hline B_power & Woman's bargaining power relative to the man & positive \\
\hline B_powersq & $\begin{array}{r}\text { The Square of the woman's bargaining power } \\
\text { relative to the man }\end{array}$ & negative \\
\hline Dep & Dependents $(<18+>60)$ & negative \\
\hline Hhsize & Household size & negative \\
\hline Male & Sex of household head & indeterminate \\
\hline Rel & Religion of household head & indeterminate \\
\hline Urban & Place of residence whether urban or rural. & positive \\
\hline Region & Regional dummy & indeterminate \\
\hline Formal & Binary & positive \\
\hline Borrow & Binary & positive \\
\hline
\end{tabular}

Source: Author, 2014

Table 1: Definition and measurement of variables. bargaining power of a woman in a rural area. This implies that women in Ghanaian urban setting have higher propensity to be empowered vis-à-vis women in the rural setting. This information is summarized in Figure 3

The bivariate analysis of women's bargaining and ownership of savings account shows that household where women have higher bargaining power leads to increased ownership of savings account among such households. Figure 4 reveals that this assertion is significant at one percent. This explains that increased women's bargaining power has a propensity to increase ownership of savings account among Ghanaian household (Figure 4).

\begin{tabular}{|c|c|}
\hline Variable & Savings account ownership \\
\hline Borrowed & $\begin{array}{c}0.712 \\
(2.29)^{\star \star}\end{array}$ \\
\hline Formal sector worker & $\begin{array}{c}0.327 \\
(5.80)^{\star \star \star}\end{array}$ \\
\hline Log income & $\begin{array}{c}0.064 \\
(4.47)^{\star \star \star}\end{array}$ \\
\hline Dependents & $\begin{array}{l}-0.052 \\
(-2.01)^{\star *}\end{array}$ \\
\hline Age & $\begin{array}{c}0.004 \\
(2.08)^{\star *}\end{array}$ \\
\hline Urban & $\begin{array}{c}0.305 \\
(5.71)^{\star \star \star}\end{array}$ \\
\hline Bargaining power & $\begin{array}{l}2.152 \\
(6.59)^{\star \star \star}\end{array}$ \\
\hline Sqr of Bargaining power & $\begin{array}{c}-2.454 \\
(-4.48)^{\star * *}\end{array}$ \\
\hline Male & $\begin{array}{l}0.317 \\
(1.60)\end{array}$ \\
\hline Household size & $\begin{array}{c}.305 \\
(5.71)^{\star \star \star}\end{array}$ \\
\hline \multicolumn{2}{|l|}{ Religion (Base $=$ No religion) } \\
\hline Christian & $\begin{array}{c}0.318 \\
(3.86)^{\star \star \star}\end{array}$ \\
\hline Muslim & $\begin{array}{l}0.132 \\
(1.34)\end{array}$ \\
\hline Traditional & $\begin{array}{c}-.044 \\
(-0.40)\end{array}$ \\
\hline \multicolumn{2}{|l|}{ Region (Base= Upper West) } \\
\hline Western & $\begin{array}{l}0.181 \\
(1.45)\end{array}$ \\
\hline Central & $\begin{array}{l}0.108 \\
(0.80)\end{array}$ \\
\hline Greater Accra & $\begin{array}{l}-0.079 \\
(-0.63)\end{array}$ \\
\hline Volta & $\begin{array}{l}0.120 \\
(0.93)\end{array}$ \\
\hline Eastern & $\begin{array}{c}0.285 \\
(2.28)^{\star \star}\end{array}$ \\
\hline Ashanti & $\begin{array}{c}0.399 \\
(3.42)^{\star \star \star}\end{array}$ \\
\hline Brong Ahafo & $\begin{array}{c}0.472 \\
(3.78)^{\star \star \star}\end{array}$ \\
\hline Northern & $\begin{array}{l}-.103 \\
(-.103)\end{array}$ \\
\hline Upper East & $\begin{array}{l}.071 \\
(0.52)\end{array}$ \\
\hline Constant & $\begin{array}{l}-2.435 \\
(-9.21)^{\star * *}\end{array}$ \\
\hline
\end{tabular}

Appendix A1: Selection equation for savings account ownership.

${ }^{*} p<0.10 \quad{ }^{* *} p<0.05 \quad$ *** $p<0.01$

Source: Computed from GLSS-5, 2005/2006 


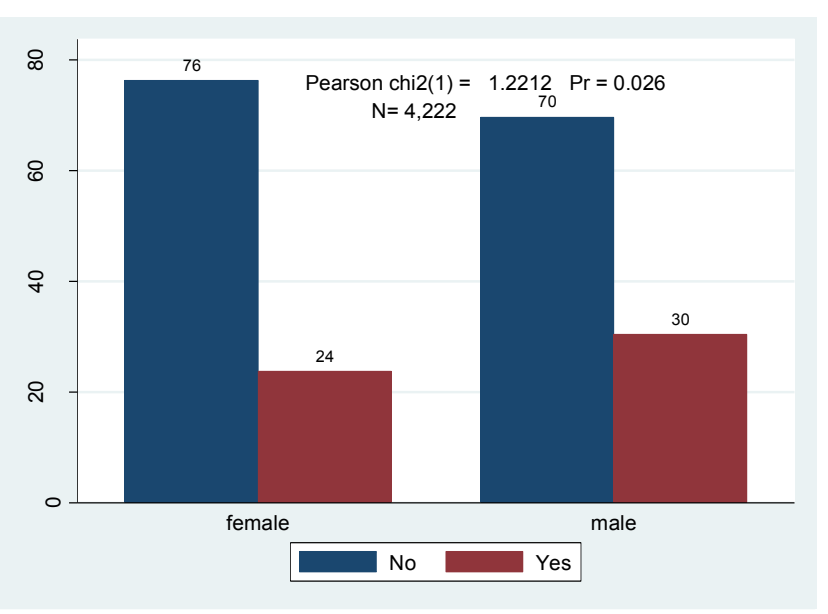

Source: Computed from GLSS-5, 2005/2006

Figure 1: Savings account ownership by sex.

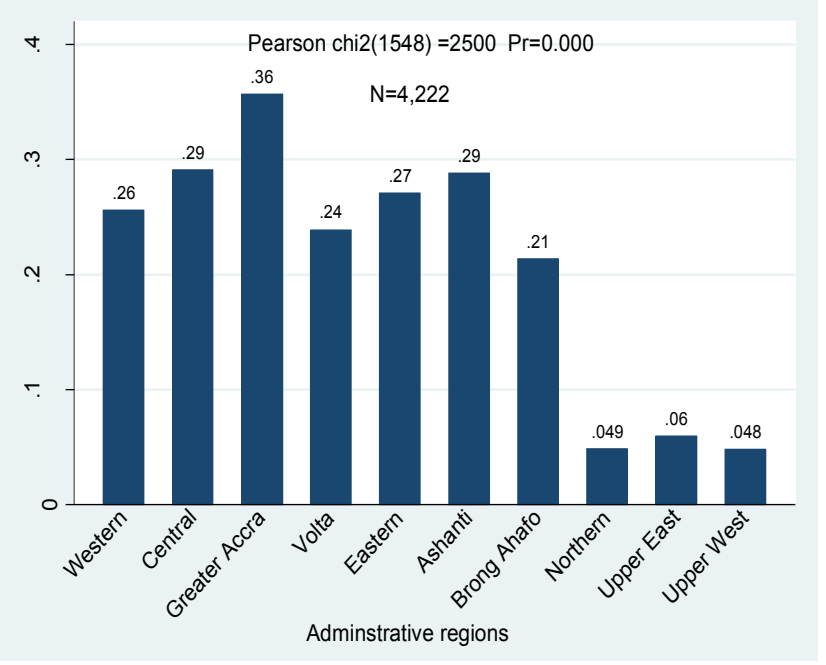

Source: Computed from GLSS-5, 2005/2006

Figure 2: Women's bargaining power across administrative regions.

\section{Regression Results}

Tables 2 present the results for the probit and Heckman twostep estimation for savings account ownership and annual savings respectively. Our post estimation tests show that the link test for specification as well as the hosmer Lemershow test of goodness of fit shows that our probit model is correctly specified and gives reliable estimates. The significant lambda coefficient in the Heckman model shows that our Heckman model is best and gives reliable estimates. Based on these we report the probit and Heckman models because they provide reliable estimates. The results show that household income does not only increases the probability that a household owns savings account but also increases the amount that a household saves annually. The study revealed that an increase in household income increases the probability that a household will own savings account by 0.025 , while 0.796 of every cedi increase in household income is saved all other things being equal. This variable is significant for savings account opening and amount saved at one percent and five percent significant level respectively. This findings is consistent with Keynes' absolute income hypothesis that savings has a positive relationship with income [14]. This supports the empirical studies by Amino et al. [15] in Mozambique, and Quartey and Blankson [16] in Ghana who also found the marginal propensity to save for households to be significant and positive (Appendix 2).

At one percent and five percent significant levels, women's bargaining power positively affects ownership of savings account as well as the amount saved among Ghanaian households. The study revealed that an increase in women's bargaining power increases the probability that a household will open savings account by 0.715 all other things being equal. While increasing the probability of savings account ownership, women's bargaining power increases household annual saving by 2265.262 Ghana cedis all other thing being equal. This positive relationship supports the study by Lundberg and WardBatts [11], who find such positive effect among American households.

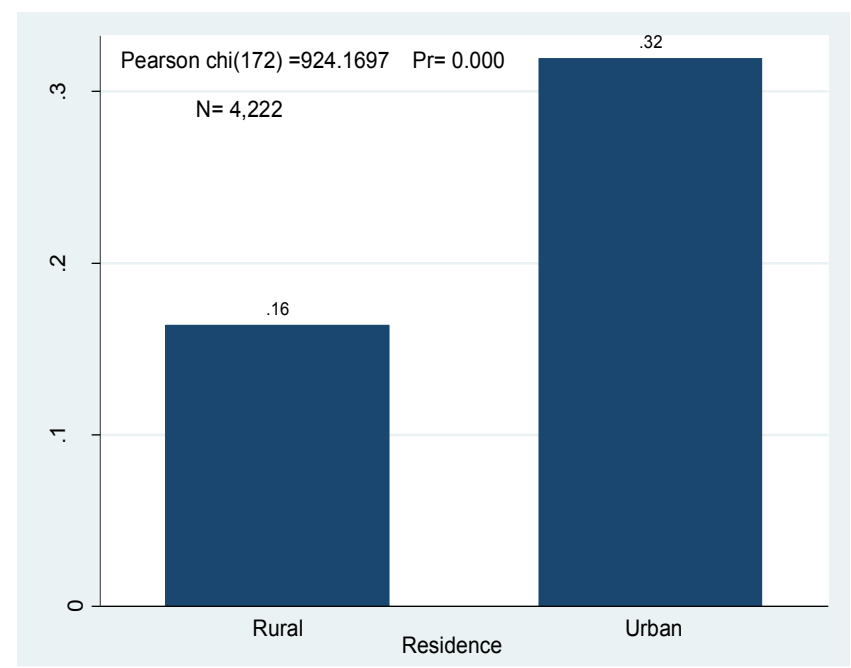

Source: Computed from GLSS-5, 2005/2006

Figure 3: Mean women bargaining power by residence.

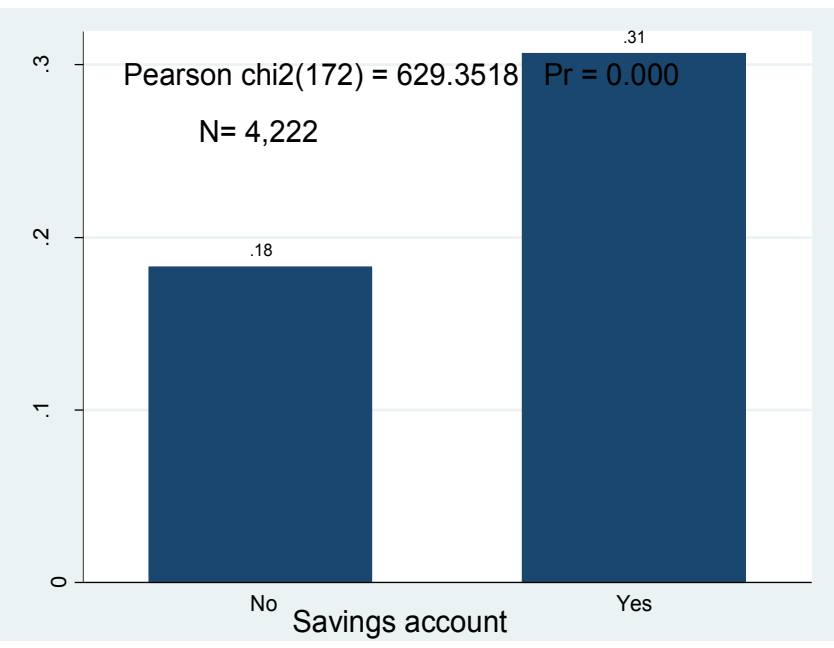

Source: Computed from GLSS-5, 2005/2006

Figure 4: Women's bargaining power and ownership of savings account. 


\begin{tabular}{|c|c|c|c|c|}
\hline & Coefficient & Marginal effect & OLS & Heckman \\
\hline Log income & $\begin{array}{c}0.082 \\
(5.07)^{\star \star \star}\end{array}$ & 0.0251 & $\begin{array}{c}24.098 \\
(0.59)\end{array}$ & $\begin{array}{l}79.662 \\
(2.11)^{* *}\end{array}$ \\
\hline Dependents & $\begin{array}{l}-0.060 \\
(-2.41)^{* *}\end{array}$ & -0.018 & $\begin{array}{c}-73.118 \\
(-1.04)\end{array}$ & $\begin{array}{l}-118.142 \\
(-2.15)^{* *}\end{array}$ \\
\hline Age & $\begin{array}{l}0.003 \\
(1.72)^{\star}\end{array}$ & 0.008 & $\begin{array}{l}10.945 \\
(2.74)^{* \star *}\end{array}$ & $\begin{array}{l}12.412 \\
(3.08)^{\star \star \star}\end{array}$ \\
\hline Urban & $\begin{array}{c}0.378 \\
(7.47)^{\star \star \star}\end{array}$ & 0.116 & $\begin{array}{c}79.356 \\
(1.41)\end{array}$ & $\begin{array}{l}314.837 \\
(2.06)^{* \star}\end{array}$ \\
\hline Bargaining power & $\begin{array}{c}2.325 \\
(7.34)^{* * *}\end{array}$ & 0.715 & $\begin{array}{c}677.655 \\
(1.49)\end{array}$ & $\begin{array}{c}2265.262 \\
(2.27)^{* *}\end{array}$ \\
\hline $\begin{array}{l}\text { Sqr of Bargaining } \\
\text { power }\end{array}$ & $\begin{array}{c}-2.852 \\
(-5.30)^{\star \star *}\end{array}$ & -0.877 & $\begin{array}{c}-421.269 \\
(-0.70)\end{array}$ & $\begin{array}{c}-2301.16 \\
(-1.80)^{*}\end{array}$ \\
\hline Male & $\begin{array}{c}0.341 \\
(1.79)^{\star}\end{array}$ & 0.103 & $\begin{array}{l}264.826 \\
(2.68)^{* * *}\end{array}$ & $\begin{array}{c}582.409 \\
(1.16)\end{array}$ \\
\hline Household size & $\begin{array}{c}0.056 \\
(1.86)^{\star \star \star}\end{array}$ & 0.017 & $\begin{array}{l}31.976 \\
(0.69)\end{array}$ & $\begin{array}{l}77.129 \\
(1.65)^{*}\end{array}$ \\
\hline \multicolumn{5}{|l|}{$\begin{array}{l}\text { Religion (Base= No } \\
\text { religion) }\end{array}$} \\
\hline Christian & $\begin{array}{c}0.353 \\
(4.63)^{\star \star \star}\end{array}$ & 0.106 & $\begin{array}{c}-274.132 \\
(-0.66)\end{array}$ & $\begin{array}{r}-55.637 \\
(-0.25)\end{array}$ \\
\hline Muslim & $\begin{array}{l}0.181 \\
(1.85)^{\star}\end{array}$ & 0.052 & $\begin{array}{c}-374.432 \\
(-0.98)\end{array}$ & $\begin{array}{c}-300.667 \\
(-1.28)\end{array}$ \\
\hline Traditional & $\begin{array}{l}-0.014 \\
(-0.12)\end{array}$ & -0.004 & $\begin{array}{c}-270.095 \\
(-0.65)\end{array}$ & $\begin{array}{l}316.19 \\
(-1.16)\end{array}$ \\
\hline Region & & $\begin{array}{c}\text { Base }= \\
\text { Greater Accra }\end{array}$ & $\begin{array}{c}\text { Base= } \\
\text { Upper West }\end{array}$ & $\begin{array}{c}\text { Base= } \\
\text { Upper West }\end{array}$ \\
\hline Western & $\begin{array}{l}0.080 \\
(0.87)\end{array}$ & 0.024 & $\begin{array}{c}365.100 \\
(1.73)^{*}\end{array}$ & $\begin{array}{c}520.988 \\
(1.66)^{\star}\end{array}$ \\
\hline Central & $\begin{array}{l}0.117 \\
(1.14)\end{array}$ & 0.036 & $\begin{array}{c}250.013 \\
(1.25)\end{array}$ & $\begin{array}{l}367.81 \\
(1.12)\end{array}$ \\
\hline Greater Accra & - & - & $\begin{array}{c}265.008 \\
(1.39)\end{array}$ & $\begin{array}{c}270.041 \\
(0.89)\end{array}$ \\
\hline Volta & $\begin{array}{l}-0.003 \\
(-0.03)\end{array}$ & -0.001 & $\begin{array}{l}85.217 \\
(0.78)\end{array}$ & $\begin{array}{c}194.548 \\
(0.60)\end{array}$ \\
\hline Eastern & $\begin{array}{c}0.215 \\
(2.34)^{\star \star}\end{array}$ & 0.067 & $\begin{array}{l}88.937 \\
(0.92)\end{array}$ & $\begin{array}{c}320.985 \\
(1.00)\end{array}$ \\
\hline Ashanti & $\begin{array}{c}0.302 \\
(2.74)^{\star \star \star}\end{array}$ & 0.096 & $\begin{array}{l}350.251 \\
(3.22)^{* * *}\end{array}$ & $\begin{array}{l}642.831 \\
(2.03)^{\star *}\end{array}$ \\
\hline Brong Ahafo & $\begin{array}{c}0.360 \\
(4.02)^{* * *}\end{array}$ & 0.096 & $\begin{array}{c}177.313 \\
(1.92)^{*}\end{array}$ & $\begin{array}{c}513.932 \\
(1.52)\end{array}$ \\
\hline Northern & $\begin{array}{l}-0.196 \\
(-1.86)^{*}\end{array}$ & -0.055 & $\begin{array}{l}214.568 \\
(1.99)^{*}\end{array}$ & $\begin{array}{c}200.333 \\
(0.59)\end{array}$ \\
\hline Upper East & $\begin{array}{l}-0.055 \\
(-0.48)\end{array}$ & -0.016 & $\begin{array}{l}289.773 \\
(3.12)^{\star \star \star}\end{array}$ & $\begin{array}{c}399.275 \\
(1.15)\end{array}$ \\
\hline Upper west & $\begin{array}{l}0.002 \\
(0.02)\end{array}$ & -0.001 & - & - \\
\hline constant & $\begin{array}{l}-2.383 \\
(-8.84)^{\ldots+}\end{array}$ & & $\begin{array}{c}-676.891 \\
(-1.83)^{\star}\end{array}$ & $\begin{array}{l}-3195.72 \\
(-2.4)^{\star *}\end{array}$ \\
\hline$N$ & 4222 & & 1220 & 4138 \\
\hline Pseudo $\mathrm{R}^{2}$ & 0.1147 & & & \\
\hline $\mathrm{R}^{2}$ & & & 0.0251 & \\
\hline lambda & & & & $\begin{array}{l}933.232 \\
(2.27)^{* *}\end{array}$ \\
\hline rho & & & & 0.548 \\
\hline sigma & & & & 1702.65 \\
\hline $\begin{array}{l}t \text { statistics in } \\
\text { parentheses }\end{array}$ & & & & \\
\hline
\end{tabular}

Table 2: Effect of women's bargaining power on savings account ownership and amount saved.

It however contradicts the findings by Gibson, Le and Scobie [12]. The positive effect suggests that empowerment of women leads to increase in household welfare through continual savings to serve as a form of insurance to cater for any fluctuations in household income. Thus, women once empowered will make sure that the financial security of the household is assured by setting aside some proportion of household generated income to be used for future consumption. Although positive, the study found that this relationship is not linear, thus, beyond a certain level of empowerment, the household savings in the household declines. In terms of saving account ownership, the study found that women's bargaining power increases the probability of owning savings account to a level beyond which this positive effect will be swept away. On the relationship between the consumption size of the household as proxied with dependents and household size, the probit model showed a negative relationship for dependents but a positive relationship for household size. The 0.018 coefficient for dependents means that an increase in the number of dependents in the household, reduces the probability that a household will own savings account all other things being equal. While an increase in household's size by one more person, increases the probability that the household will own savings account by 0.017 . This explains that the more the size of the household increases, the more members can contribute resources towards the pool of income. The positive coefficient suggests that when resources are pooled in the household there will be a surplus income which will be channeled toward savings account ownership. The results from the Heckman estimation suggest that an increase in the number of dependents in the household reduces household annual savings by 118.142 Ghana cedis while an increase in household size increases households' annual savings by 77.129 Ghana cedis all other things being equal. This findings support Loayza, Schmidt-Hebber, and Serven [17] in their panel evidence the young age dependency ratio leads to a decline in the private financial savings rate. This suggests that the presence of many children and elderly people in the household, the less the household can save. Other control variables such as age and urban dwelling positively predict savings. At five percent significant level as a person advances in age, the probability of owing savings account increases by 0.008 while increasing the quantum of annual savings by 12.142 Ghana cedis all other factors held constant. This finding is in line with Ando and Modigliani [18] life cycle hypothesis that suggest that people save when young to finance consumption during retirement. This also supports the empirical finding by Quartey and Blankson [16] who found that children and the aged on average have higher savings

\begin{tabular}{|c|c|c|c|c|c|}
\hline Variable & Observations & Mean & $\begin{array}{c}\text { Standard } \\
\text { Deviation }\end{array}$ & Minimum & Maximum \\
\hline $\begin{array}{c}\text { Saving account } \\
\text { ownership }\end{array}$ & 4222 & 0.303 & 0.459 & 0 & 1 \\
\hline Amount saved & 1220 & 371.708 & 1528.868 & 0 & 30000 \\
\hline Dependents & 4222 & 2.766 & 1.774 & 0 & 12 \\
\hline Bargaining power & 4222 & 0.220 & 0.237 & 0 & 1 \\
\hline Bargaining power sqr & 4222 & 0.105 & 0.1329 & 0 & 1 \\
\hline Log income & 4222 & 6.394 & 1.749 & 0 & 10.808 \\
\hline Age & 4222 & 44.727 & 13.892 & 18 & 99 \\
\hline Male & 4222 & 0.986 & 0.1173 & 0 & 1 \\
\hline Household size & 4222 & 5.139 & 2.144 & 2 & 21 \\
\hline Urban & 4222 & .3647 & 0.481 & 0 & 1 \\
\hline Religion & 4222 & 1.359 & 0.812 & 0 & 3 \\
\hline Region & 4222 & 5.399 & 2.673 & 1 & 10 \\
\hline Formal sector & 4222 & .0047 & 0.069 & 0 & 1 \\
\hline Borrowed & 4222 & .2359 & 0.425 & 0 & 1 \\
\hline
\end{tabular}

Source: Computed from GLSS-5, 2005/20065

Appendix A2: Summary statistics for variables used for the analysis. 
balances than the working population in Ghana. Regarding residential setting, urban dwellers have a probability of 0.116 to open savings account while increasing their annual savings by 314.837 Ghana cedis. In Ghana, support of this finding [19], put forward that rural dwellers are not only discriminated in terms of banks (financial institutions) location but are also known to be relatively poor compared to urban dwellers. This therefore impact on their savings adversely. This justifies why urban dwellers save more than rural dwellers. This finding is in line with that of Olurinola [20], who find similar effect in South-Western Nigeria (Table 2).

\section{Conclusion}

This paper has empirically examined the effect of women's bargaining power on household saving. Probit and Heckman models for savings account ownership and annual savings were estimated. It was found that an increase in women bargaining power increases the probability that a household owning savings account while increasing household annual savings all other things being equal. Other control variables such as household income, household size and urban dwelling engender positive household savings. As a way of increasing household savings in Ghana, we recommend that women empowerment through better education should be considered as a panacea to ensure improvement in household savings. Household income levels should also be improved perhaps through creation of job avenues, so that economically active household members can be working to increase the overall household income in order to engender increase in household savings in Ghana.

\section{References}

1. Sutton CN, Jenkins B (2007) The role of the financial services sector in expanding economic opportunity.

2. Honohan $P$ (2008) Cross-country variation in household access to financial services. Journal of Banking and Finance 32: 2493-2500.

3. Beck T, Demirgüç-Kunt A, Levine R (2007) Finance, inequality and the poor. Journal of economic growth 12: $27-49$
4. Jalilian H, Kirkpatrick C (2005) Does financial development contribute to poverty reduction?. Journal of Development Studies 41: 636-656.

5. Quartey $P$ (2005) Financial sector development, savings mobilization and poverty reduction in Ghana (No. UNU-WIDER).

6. Gravelle H, Rees R (2004) Microeconomics. Prentice Hall, UK.

7. Basu A, Blavy R, Yulek M (2004) Microfinance in Africa: Experience and Lessons from Selected African Countries. IMF-International Monetary Fund.

8. World Bank Group (2012) World Development Indicators 2012. World Bank Publications.

9. Demirgüç-Kunt A, Klapper LF (2012) Measuring financial inclusion: The global findex database. World Bank Policy Research Working Paper.

10. Ferber R (1973) Consumer economics, a survey. Journal of Economic Literature 11: 1303-1342.

11. Lundberg SJ, Ward-Batts J (2000) Saving for retirement: Household bargaining and household net worth.

12. Gibson J, Le T, Scobie G (2006) Household bargaining over wealth and the adequacy of women's retirement incomes in New Zealand. Feminist Economics 12: $221-246$.

13. Doss CR (1996) Women's bargaining power in household economic decisions: Evidence from Ghana.

14. Keynes JM (1936) The general theory of interest, employment and money.

15. Amimo O, Larson DW, Bittencourt M, Graham DH (2004) The potential for financial savings in rural Mozambican households. Savings and Development 28: 157-178.

16. Quarterly P, Blankson T (2004) Do Migrant Remittances Minimize the Impact of Macro-Volatility on the Poor in Ghana.

17. Loayza N, Schmidt-Hebbel K, Servén L (2000) What drives private saving across the world? Review of Economics and Statistics 82: 165-181.

18. Ando A, Modigliani F (1963) The" life cycle" hypothesis of saving: Aggregate implications and tests. The American economic review 53: 55-84.

19. Amoa-Mensah JJ, Aubyn A, Amoah I, Opoku C, Amponsah P, et al. (2013) Challenges Faced By Farmers In Accessing Credit From Rural Banks.

20. Olurinola IO (1992) Determinants of Informal Savings in South Western Nigeria Savings and Development 25: 225-251. 